\author{
Paulina REWERS ${ }^{1}$ \\ Justyna TROJANOWSKA ${ }^{2}$ \\ Przemyslaw CHABOWSKI ${ }^{3}$ \\ Krzysztof ŻYWICKI ${ }^{4}$
}

\title{
IMPACT OF KAIZEN SOLUTIONS ON PRODUCTION EFFICIENCY
}

The aim of this article is to demonstrate the impact of creativity and employee involvement in improving their workplaces on productivity.

The article shows an example of the involvement of employees in the improvement actions on their work environment. Pattern, where employees are aware of their role in the production process and the impact on its realization are the basic principles of Kaizen. Thanks to this activity, it is possible to create employee motivation to improve their job according to their own needs and requirements. Choice of the topic results from the conviction that the proper motivation of production employees leads to an increase of their commitment to work and improving their production station translates into an increase in the efficiency of the whole production process. Proper use of employees ideas, brings positive results in better use of available resources of the company.

An article includes an example of using the employees suggestions system in the company from the metal industry. Performance analyse of the workstation was made before and after the implementation of kaizen along with the implemented improvement solutions. Authors through their research showed that the greater the involvement of employees in improving their workplace (which is a direct result of the suggestion system implemented in the company), than the greater performance of this position.

Keywords: Kaizen, Lean Manufacturing, improvement, employee involvement, employee suggestion system

\section{INTRODUCTION}

Kaizen is a philosophy for continuous improvement of the company and approach it to perfection. Kaizen refers to a small, gradual improvements incurred as a result of efforts. The aim of kaizen is to improve individual operations and processes by eliminating waste and improving value-added activities. The Kaizen philosophy has been implemented in organizations around the world as a way to improve production values while also improving employee morale and safety. The Kaizen philosophy may be applied to any workplace scenario due to its simple nature.The first scientific publication indexed in Scopus on the subject of kaizen is a conference paper "Towards Balanced appropriately factory automation" presented by a scien-

\footnotetext{
${ }^{1}$ M. Sc. Eng., Paulina Rewers, Chair of Management and Production Engineering, Poznan University of Technology, Poznan, Piotrowo 3 Str, 60-965 Poznan, phone: +48 (61) 6475991.

${ }^{2}$ M. Sc. Eng., Justyna Trojanowska, Chair of Management and Production Engineering, Poznan University of Technology, Poznan, Piotrowo 3 Str, 60-965 Poznan, phone: +48 (61) 6475991.

${ }^{3}$ M. Sc. Eng., Przemysław Chabowski, Chair of Management and Production Engineering, Poznan University of Technology, Poznan, Piotrowo 3 Str, 60-965 Poznan, phone: +48 (61) 6475991

${ }^{4}$ PhD. Eng., Krzysztof Żywicki, Chair of Management and Production Engineering, Poznan University of Technology, Poznan, Piotrowo 3 Str, 60-965 Poznan, phone: +48 (61) 6475991
} 
tist from the University in Oakland at 8th International Conference on Production Research in Stuttgart in 1985. The number of scientific publications indexed in Scopus on the subject of kaizen in individual years is shown in Fig.1.

The issue of Kaizen is discussed in various scientific fields, but most often in scientific publications in the field of engineering sciences (54.7\% of all publications), followed by management (28.6\% of all publications) and computer science (12.7\% of all publications). The growing interest in the concept of Kaizen among scientists is reflected also in enterprises. Companies are increasingly willing to start improving processes in their companies of implementing the Kaizen concept. The main advantage of Kaizen is the fact that all company's employees are involved in improving processes through the ability to report on the conclusions of kaizen ideas. The involvement of employees guarantees durability of the implemented solutions.

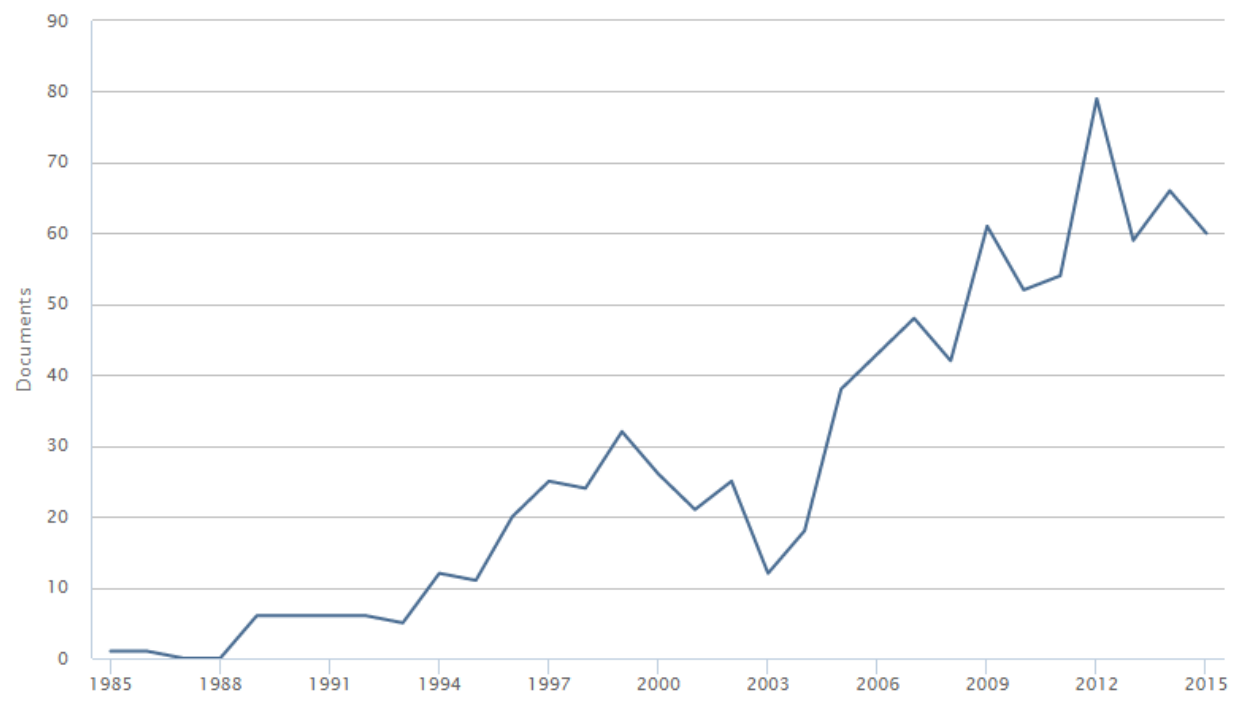

Fig. 1. The number of scientific publications on the subject of kaizen indexed in Scopus

Source: own.

\section{LITERATURE REVIEW}

The economic situation of the country and the position of manufacturing enterprises among the competitors forces the manufacturers to use methods of improving production processes that allow the reduce production costs and increase productivity. The concept, which allows the improvement of manufacturing processes, is Lean Manufacturing (LM). Primarily a LM assumes the elimination of all waste (jap. Muda) occurring on production $^{5}$. This concept is derived from the production system TPS (Toyota Production System), whose creators were Japanese engineers: Sakichi Toyoda, Ki'ichirō Toyoda and Taiichi Ohno. It is they who in the early twentieth century revolutionized manufacturing

\footnotetext{
${ }^{5}$ J. K. Liker, D. P. Meier, Droga Toyoty Fieldbook. Praktyczny przewodnik wdrażania 4P Toyoty, Wyd. MT Biznes, Warszawa, 2011.
} 
Toyota Group ${ }^{6}$. Taiichi $\mathrm{Ohno}^{7}$ in his works devoted to the frugal production of listed seven types of waste: overproduction, errors and quality defects, waiting, over-processing, transport superfluous and movement superfluous. Currently, seven types of waste is enriched by yet another - untapped potential employee. In this context, it is meant ignoring or not using of ideas, competence, talent and time employee ${ }^{8}$.

Manufacturing enterprises to eliminate waste, presented the use of one of the tools of Lean Manufacturing which is Kaizen. In Japan, Kaizen means continuous improvement ${ }^{9}$ ${ }^{10}$. It is run slowly, increasing from time to time but continuously. Meanwhile, in America it is known as "Kaizen Blizt" or "Kaizen Event" ${ }^{11}$. According to Imai ${ }^{12}$ Kaizen is a continuous improvement process involving every one, managers and workers. Cheser ${ }^{13}$ explains that Kaizen means making small changes on a regular basis by reducing waste and continuously improving productivity, safety, and effectiveness. Suzaki ${ }^{14}$ explains that Kaizen is a philosophy widely practiced in belief that, that there is no end to make a process better. Each small improvement consists of many levels of development, mainly used for improving manufacturing processes.

Application process of kaizen method basically consists of ${ }^{15}$ :

- definition of the improvement area,

- analysis and selection of the key problem,

- identification of the cause of improvement,

- planning the remedial center measures,

- implementation of the improving project,

- measuring, analyzing and comparison of the results,

- standardization.

${ }^{6}$ J. K. Liker, J. K. Franz, The Toyota Way to Continuous Improvement, Linking Strategy and Operational Excellence to Achieve Superior Performance, The McGraw-Hill Companies, United States of America, 2011.

${ }^{7}$ T. Ohno, System Produkcyjny Toyoty. Więcej niż produkcja na duża skalę, Wyd. ProdPress.com, Wrocław, 2008, pp. 17.

${ }^{8}$ M. Rother, J. Shook J., Learning to see: value stream mapping to create value and eliminate muda, Brookline, Lean Enterprise Institute, Wrocław 1990.

${ }^{9}$ M. Norhasni, M. Asaad, R. Saad, R. Z. Yusoff, 5s, Kaizen and Organization Performance: Examining the Relationship and Level of Implementation Using Rasch Model in Malaysian Automotive Company, International "Academic Research Journal of Business and Technology", pp. 214-226.

${ }^{10}$ M. F. Suárez-Barraza, T. Smith, The Kaizen approach within process innovation: findings from a multiple case study in Ibero-American countries, "Total Quality Management \& Business Excellence" 2014, 25(9-10), pp. 1002.

${ }^{11}$ J. A. Marin-Garcia, J. J. Garcia-Sabater, T. Bonavia, The impact of Kaizen Events on improving the performance of automotive components' first-tier suppliers, „International Journal of Automotive Technology and Management“" 2009, Volume 9, Issue 4, pp.362 - 376.

${ }^{12}$ M. Imai, Kaizen: The Key to Japan's Competitive Success, Random House Published, New York, 1986.

${ }^{13}$ R. N. Cheser, The Effect of Japanese Kaizen on Employee Motivation in US Manufacturing, "International Journal Organizational Analysis" 1998, Vol. 6, No. 3, pp. 197-212.

${ }^{14}$ K. Suzaki, The New Manufacturing Challenge-Techniques of Manufacturing Systems, John Wiley and Sons, Inc., New York, 1987.

${ }^{15}$ T. Asada, J. C. Bailes, K. Suzuki, Implementing ABM with Hoshin Management, Institute of Management Accountants Publ., New Jersey, 2000; R. Kraszewski R., Quality management - conceptions, methods and tools used by the world's business leaders, "Scientific society of management Published", Torun 2005; M. Musztyfaga, Skoud B., Human resources management in a project type tasks, "Journal of Achievements in Materials and Manufacturing Engineering" 2007, 25/2, pp.95-98. 
The Kaizen is dedicated to the improvement of productivity, efficiency, quality and of business excellence ${ }^{16}$.

\section{COMPANY DESCRIPTION}

The research was conducted in a large European manufacturing company which is an official supplier and technological partner of a vast majority of the vehicle producing companies from all over the world. The Company was set up in 1949 producing mechanical cables for the spare parts market. In that time, the automobile industry was nearly inexistent in Spain. Between the 50's and the 70's, several makers, such as Seat, Barreiros, Avia and Iomsa, Fasa Renault, Pegaso, Ford, Mercedes, Citroën, Peugeot and Motor Ibérica among others, decided to establish themselves in the country. The Company decided a change in strategy and focused it in becoming a supplier for these brands. Following this path, The Company grows and consolidates as the Spanish leader in its different lines of product, though benefited by the political environment and closed markets. On the one hand, the protectionist Spanish legislation of that time obliged the car builders which were established in the country to have Spanish main suppliers. On the other hand, the builders' decisions were decentralized at every country they operated, which helped The Company be near the customers and know first-hand their needs and habits. During this first stage, The Company begins its expansion abroad, deciding to establish itself in Oporto in Portugal in the beginning of the 70's. Nowadays The Company has production centers, engineering centers and commercial offices in 19 countries in Europe, North America, South America and Asia. The Company has a team of 8.661 professionals working all around the world, invests a $4 \%$ of its turnover in R\&D every year and in 2012 , the Group invoiced 953 million Euro.

In order to constantly improve the company decided to implement kaizen in the production system. Pilot implementation was made on the production line producing one of the handles.

The main goals that The Company intended to achieve through the implementation of kaizen were as follows:

- Increase the productivity,

- Reduce manufacturing cycle,

- Reduce manufacturing area,

- Reduce work in progress,

- Increase the quality,

- Flexible line according to the customer requirements,

- Improve ergonomics and security of work

It should be noted that, in according to management wishes, goals were set quite generally, without specifying numerical values. A common practice is to set specific numerical values to be pursued. The term numerical targets help to evaluate the efficiency and effectiveness of these actions.

At the first meeting the working team established a detailed work plan consisting of the stages as show in fig. 2 .

\footnotetext{
${ }^{16}$ M. A. Titu, C. Operan, D. Grecu, Applying the Kaizen Method and the 5S Technique in the Activity of PostSale Services in the Knowledge-Based Organization, "Proceedings of the International MultiConference of Engineers and Computer Scientists”2010, Vol. III, IMECS, Hong Kong, March 17-19.
} 


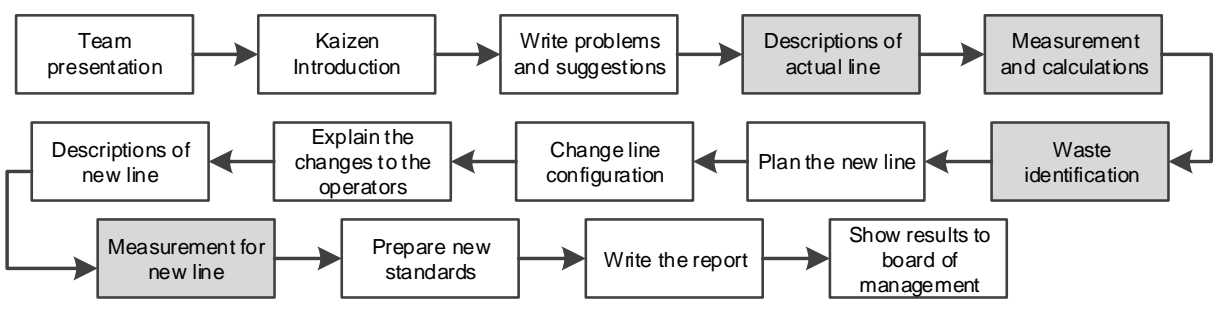

Fig. 2. Work plan

Source: own.

Due to the limited volume of the article in this publication selected steps of improvement are shown in Figure 2 in gray.

\section{MEASUREMENT AND CALCULATIONS}

Figure 3 shows lay out of the line before kaizen activities.

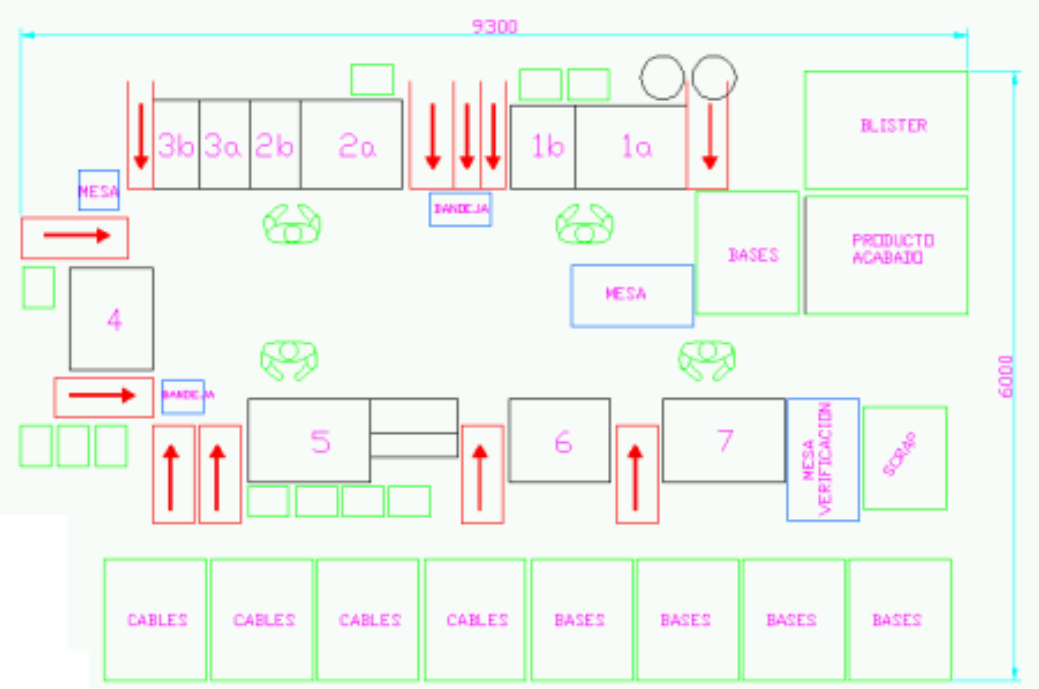

Fig.3. Initial layout of the line

Source: own.

Initial data of the process before Kaizen for one of the production line was as follow:

- Number of workers per turns - 7 operators,

- Volume of production per day (two turns) - 392 pieces,

- Productivity [units/hour/person] - 3,5,

- Area of the line $-9,3 \times 6=55,8 \mathrm{~m} 2$,

- Work in progress -30 handles.

Total work time of 8 hours (480 minutes) in a shift (gross time) less 15 minutes breakfast, 15 minutes for break, 10 minutes for cleaning and 20 minutes for changeover, then the net Available Time to Work $=480-15-15-10-20=420$ minutes, which is 25200 
seconds in turn, so 50400 seconds per day. Customer demand is 427 units a day, so tact time for this production line is 118 seconds.

In table 1-7, information's about measurement of time used by operator no.1-7 in each operation before Kaizen are shown.

Table 1 . Time of the operation by operator no. 1

Operator no.1
Task 1: Take base and position in useful, press button, take Lever, Joint Socket and set in Lever,
turn Joint Socket in the other side, place Lever in useful grease and grease, place Joint Socket in the
correct position, set 1st Semisocket in Lever and set everything with the Base, take out Base from
useful and check if Semisocket is in the right position, place again the Base in the useful and set the
2nd Semisocket. Take placket and set with Base, screw with 2 screws, check screwed pressing
button and take out the Base pressing the bimanual.
\begin{tabular}{|c|c|c|c|c|c|c|c|c|c|c|}
\hline \multicolumn{10}{|c|}{ No. of measurement } & Average \\
\hline 1 & 2 & 3 & 4 & 5 & 6 & 7 & 8 & 9 & 10 & 57,6 \\
\hline 53,1 & 56,3 & 64,7 & 55,9 & 60,2 & 55,2 & 53,3 & 54,0 & 67,3 & 56,2 & 5 \\
\hline \multicolumn{70}{|c|}{ Time [sec] } \\
\hline
\end{tabular}

Task 2: Move from place to place, take out cart and take out old Base and leave in a tray, position Base in nailed useful, to face up Sub. Bracket Guide Ball to Lever, press button and introduce the tray, press bimanual to nail Sub. Bracket Guide Ball and move from place to place.

\begin{tabular}{|c|c|c|c|}
\hline $\begin{array}{c}\text { No. of measure- } \\
\text { ment }\end{array}$ & Time [sec] & $\begin{array}{c}\text { No. of measure- } \\
\text { ment }\end{array}$ & Time [sec] \\
\hline 1 & 8,6 & 6 & 8,6 \\
\hline 2 & 8,6 & 7 & 8,6 \\
\hline 3 & 8,6 & 8 & 8,6 \\
\hline 4 & 8,6 & 9 & 8,6 \\
\hline 5 & 8,6 & 10 & 8,6 \\
\hline \multicolumn{2}{|c}{ Average time [sec] } & $\mathbf{8 , 6}$ \\
\hline
\end{tabular}

Total time in process for operator no.1

\begin{tabular}{|c|c|c|c|c|c|c|c|c|c|c|}
\hline \multicolumn{10}{|c|}{ No. of measurement } & \multirow{2}{*}{ Average } \\
\hline 1 & 2 & 3 & 4 & 5 & 6 & 7 & 8 & 9 & 10 & \\
\hline 61,7 & 64,9 & 73,3 & 64,5 & 68,8 & 63,8 & 61,9 & 62,6 & 75,9 & 64,8 & 66,2 \\
\hline \multicolumn{10}{|c|}{ Time [sec] } \\
\hline
\end{tabular}

Source: own 
Impact of Kaizen solutions on...

Table 2. Time of the operation by operator no. 2

\section{Operator no.2}

Task 1: Take Base and position in useful, press bimanual to lock, take Selector and grease with the paintbrush, take Spring and Locker Badge and set in Selector, set everything in Base, take two Badges and set in Base, insert the tray and press bimanual, take out the last Base from place $2 \mathrm{~b}$ and leave in $3 \mathrm{a}$, come back to $2 \mathrm{a}$, take out the Base and leave in $2 \mathrm{~b}$.

\begin{tabular}{|c|c|c|c|c|c|c|c|c|c|c|}
\hline \multicolumn{10}{|c|}{ No. of measurement } & \multirow{2}{*}{ Average } \\
\hline 1 & 2 & 3 & 4 & 5 & 6 & 7 & 8 & 9 & 10 & 30,9 \\
\hline 33,0 & 28,9 & 29,6 & 29,8 & 30,2 & 33,2 & 30,1 & 29,4 & 32,8 & 31,9 & \\
\hline \multicolumn{10}{|c|}{ Time [sec] } \\
\hline
\end{tabular}

Task 2: Put Base in 2b, take Shift Lock and Shaft Shift Lock and set in the Base, press Bimanual.

\begin{tabular}{|c|c|c|c|}
\hline $\begin{array}{c}\text { No. of measure- } \\
\text { ment }\end{array}$ & Time [sec] & $\begin{array}{c}\text { No. of measure- } \\
\text { ment }\end{array}$ & Time [sec] \\
\hline 1 & 10,0 & 6 & 10,0 \\
\hline 2 & 10,0 & 7 & 10,0 \\
\hline 3 & 10,0 & 8 & 10,0 \\
\hline 4 & 10,0 & 9 & 10,0 \\
\hline 5 & 10,0 & 10 & 10,0 \\
\hline \multicolumn{3}{|c}{ Average time [sec] } & $\mathbf{1 0 , 0}$ \\
\hline
\end{tabular}

Total time in process for operator no.2

\begin{tabular}{|c|c|c|c|c|c|c|c|c|c|c|}
\hline \multicolumn{10}{|c|}{ No. of measurement } & \multirow{2}{*}{ Average } \\
\hline 1 & 2 & 3 & 4 & 5 & 6 & 7 & 8 & 9 & 10 & \\
\hline 43,0 & 38,9 & 39,6 & 39,8 & 40,2 & 43,2 & 40,1 & 39,4 & 42,8 & 41,9 & 40,9 \\
\hline \multicolumn{10}{|c|}{ Time [sec] } \\
\hline
\end{tabular}

Source: own. 
Table 3. Time of the operation by operator no. 3

\begin{tabular}{|c|c|c|c|c|c|c|c|c|c|c|}
\hline \multicolumn{11}{|c|}{ Operator no.3 } \\
\hline \multicolumn{11}{|c|}{$\begin{array}{l}\text { Task 1: Take base and put in } 3 \mathrm{~b} \text {, connect the circuit with the solenoid, set Circuit in the Base an } \\
\text { point the solenoid to the Base, position Base in } 3 \mathrm{a} \text {, press bimanual, face up Solenoid in useful an } \\
\text { lower the manual press, position Base in } 3 \mathrm{a} \text {, take screw and screw to fix the solenoid, take out an } \\
\text { leave in next station. }\end{array}$} \\
\hline \multicolumn{10}{|c|}{ No. of measurement } & \multirow{2}{*}{ Average } \\
\hline 1 & 2 & 3 & 4 & 5 & 6 & 7 & 8 & 9 & 10 & \\
\hline 53,7 & 54,2 & 56,5 & 48,7 & 56,3 & 62,2 & 48,5 & 51,9 & 60,5 & 56,2 & 54,9 \\
\hline \multicolumn{11}{|c|}{ Time [sec] } \\
\hline \multicolumn{11}{|c|}{ Total time in process for operator no.3 } \\
\hline \multicolumn{10}{|c|}{ No. of measurement } & \multirow{2}{*}{ Average } \\
\hline 1 & 2 & 3 & 4 & 5 & 6 & 7 & 8 & 9 & 10 & \\
\hline 53,7 & 54,2 & 56,5 & 48,7 & 56,3 & 62,2 & 48,5 & 51,9 & 60,5 & 56,2 & 54,9 \\
\hline \multicolumn{11}{|c|}{ Time [sec] } \\
\hline
\end{tabular}

Source: own.

Table 4. Time of the operation by operator no. 4

\section{Operator no.4}

Task 1: Take Base and put pressing a button, take Detent grease "valleys and mountains" zone and set in Base, screw (x4) the Detent, check Lever movement, take and set superior joint and check screw approaching the tester and pressing bimanual, take out the tester and take out the lever.

\begin{tabular}{|c|c|c|c|c|c|c|c|c|c|c|}
\hline \multicolumn{10}{|c|}{ No. of measurement } & \multirow{2}{*}{ Average } \\
\hline 1 & 2 & 3 & 4 & 5 & 6 & 7 & 8 & 9 & 10 & 50,6 \\
\hline 35,0 & 50,4 & 50,8 & 48,0 & 48,3 & 50,1 & 51,9 & 60,7 & 56,9 & 53,9 & \\
\hline \multicolumn{10}{|c|}{ Time [sec] } \\
\hline
\end{tabular}

Total time in process for operator no.4

\begin{tabular}{|c|c|c|c|c|c|c|c|c|c|c|}
\hline \multicolumn{10}{|c|}{ No. of measurement } & \multirow{2}{*}{ Average } \\
\hline 1 & 2 & 3 & 4 & 5 & 6 & 7 & 8 & 9 & 10 & \\
\hline 35,0 & 50,4 & 50,8 & 48,0 & 48,3 & 50,1 & 51,9 & 60,7 & 56,9 & 53,9 & 50,6 \\
\hline \multicolumn{10}{|c|}{ Time [sec] } \\
\hline
\end{tabular}

Source: own. 
Impact of Kaizen solutions on...

Table 5. Time of the operation by operator no. 5

Operator no.5
Task 1: Take a Lever and position in useful, take Lead and Back Foam and set in the Lever, take
cable and face up to the Base, TC Coco Vikingo visual checking, put Coco Vikingo in useful, move
to the right side and join Kneecap Seat with Kneecap, take a Staple and put in Base, paint TF with
felt tip pen and press bimanual and take out Lever + Cable.
\begin{tabular}{|c|c|c|c|c|c|c|c|c|c|c|}
\hline \multicolumn{10}{|c|}{ No. of measurement } & Average \\
\hline 1 & 2 & 3 & 4 & 5 & 6 & 7 & 8 & 9 & 10 & 60,0 \\
\hline 51,7 & 56,8 & 64,2 & 62,0 & 57,1 & 62,8 & 59,0 & 58,6 & 64,0 & 63,5 & \\
\hline \multicolumn{70}{|c|}{ Time [sec] } \\
\hline
\end{tabular}

Total time in process for operator no.5

\begin{tabular}{|c|c|c|c|c|c|c|c|c|c|c|}
\hline \multicolumn{10}{|c|}{ No. of measurement } & \multirow{2}{*}{ Average } \\
\hline 1 & 2 & 3 & 4 & 5 & 6 & 7 & 8 & 9 & 10 & \\
\hline 51,7 & 56,8 & 64,2 & 62,0 & 57,1 & 62,8 & 59,0 & 58,6 & 64,0 & 63,5 & 60,0 \\
\hline \multicolumn{10}{|c|}{ Time [sec] } \\
\hline
\end{tabular}

Source: own.

Table 6 . Time of the operation by operator no. 6

Operator no.6
Task 1: Take a Lever + Cable and put in useful, set Lower Joint, set Lid and press bimanual, ta
out, check Lid join and set again Superior Joint.
\begin{tabular}{|c|c|c|c|c|c|c|c|c|c|c|}
\hline \multicolumn{10}{|c|}{ No. of measurement } & \multirow{2}{*}{ Average } \\
\hline 1 & 2 & 3 & 4 & 5 & 6 & 7 & 8 & 9 & 10 & 40,0 \\
\hline 39,0 & 41,7 & 40,5 & 39,1 & 41,0 & 40,7 & 40,7 & 40,1 & 39,5 & 37,7 & \\
\hline \multicolumn{10}{|c|}{ Time [sec] } \\
\hline
\end{tabular}

Total time in process for operator no.6

\begin{tabular}{|c|c|c|c|c|c|c|c|c|c|c|}
\hline \multicolumn{10}{|c|}{ No. of measurement } & \multirow{2}{*}{ Average } \\
\hline 1 & 2 & 3 & 4 & 5 & 6 & 7 & 8 & 9 & 10 & \\
\hline 39,0 & 41,7 & 40,5 & 39,1 & 41,0 & 40,7 & 40,7 & 40,1 & 39,5 & 37,7 & 40,0 \\
\hline \multicolumn{10}{|c|}{ Time [sec] } \\
\hline
\end{tabular}

Source: own. 
Table 7. Time of the operation by operator no. 7

Operator no.7
Task 1: Take Lever + Cable and put in useful for a final test, press bimanual.
\begin{tabular}{|r|c|c|c|c|c|c|c|c|c|r|}
\hline \multicolumn{10}{|c|}{ No. of measurement } \\
\hline 1 & 2 & 3 & 4 & 5 & 6 & 7 & 8 & 9 & 10 & \multirow{2}{*}{ Average } \\
\hline 6,9 & 5,7 & 7,0 & 6,8 & 4,8 & 6,0 & 7,0 & 6,9 & 6,9 & 6,7 & 6,5 \\
\hline \multicolumn{10}{|c|}{ Time [sec] } \\
\hline
\end{tabular}

Task 2: Stick label in the front Lever, check feeling and leave in a container.

\begin{tabular}{|c|c|c|c|}
\hline $\begin{array}{c}\text { No. of measure- } \\
\text { ment }\end{array}$ & Time [sec] & $\begin{array}{c}\text { No. of measure- } \\
\text { ment }\end{array}$ & Time [sec] \\
\hline 1 & 35,0 & 6 & 33,3 \\
\hline 2 & 27,4 & 7 & 32,3 \\
\hline 3 & 30,0 & 8 & 28,6 \\
\hline 4 & 37,3 & 9 & 30,6 \\
\hline 5 & 39,0 & 10 & 32,9 \\
\hline \multicolumn{2}{|c|}{ Average time [sec] } & \multicolumn{2}{|l|}{32,6} \\
\hline
\end{tabular}

Task 3: Register in Final Check List and take out Lever from useful from Final Test.

\begin{tabular}{|c|c|c|c|c|c|c|c|c|c|c|}
\hline \multicolumn{10}{|c|}{ No. of measurement } & \multirow{2}{*}{ Average } \\
\hline 1 & 2 & 3 & 4 & 5 & 6 & 7 & 8 & 9 & 10 & 11,1 \\
\hline 8,3 & 13,2 & 12,8 & 11,2 & 8,9 & 10,0 & 12,0 & 14,0 & 13,3 & 7,7 & 1 Time [sec] \\
\hline
\end{tabular}

Total time in process for operator no.7

\begin{tabular}{|c|c|c|c|c|c|c|c|c|c|c|}
\hline \multicolumn{10}{|c|}{ No. of measurement } & \multirow{2}{*}{ Average } \\
\hline 1 & 2 & 3 & 4 & 5 & 6 & 7 & 8 & 9 & 10 & \multirow{2}{*}{ Time [sec] } \\
\hline 50,2 & 46,3 & 49,8 & 55,3 & 52,7 & 49,3 & 51,3 & 49,5 & 50,8 & 47,3 & \\
\hline \multicolumn{10}{|c|}{} \\
\hline
\end{tabular}

\section{Source: own}

Table 8. shows time that each worker spends in each step of his work and the total time spent in the whole process

Table 8. Time per operator - before Kaizen

\begin{tabular}{|c|c|c|c|c|c|c|c|}
\hline Operator no. & 1 & 2 & 3 & 4 & 5 & 6 & 7 \\
\hline $\begin{array}{c}\text { Total time } \\
\text { [sec] }\end{array}$ & 66,2 & 40,9 & 54,9 & 50,6 & 60,0 & 40,0 & 50,2 \\
\hline \multicolumn{7}{|c|}{ The cycle time is 362,8 seconds. } \\
\hline
\end{tabular}

Source: own. 


\section{WASTE IDENTIFICATION}

Very important step in improving production system was to identify all the waste, in lean manufacturing conception it is named Muda. Kaizen team defined seven kinds of waste are shown in table 9.

Table 9. Waste identified by Kaizen team

\begin{tabular}{|c|l|}
\hline Kind of waste & \multicolumn{1}{c|}{ Identified examples } \\
\hline \multirow{3}{*}{ Overproduction } & - Accumulation of work in progress. \\
& - Objectives and achievements are not clear. \\
& - The quantity of pieces to manufacture is out of control. \\
\hline \multirow{2}{*}{ Waiting } & - Operators without work. \\
& - Low rhythm of the operators. \\
\hline \multirow{2}{*}{ Transport } & - Loading and unloading are very complicated. \\
& - A large number of means of transport. \\
\hline \multirow{3}{*}{ Over pro- } & - Differences between the operators. \\
cessing & - Differences between the standard and the activity. \\
& - A lot of activity which does not add any value from the point of \\
& view of the customer. \\
\hline \multirow{3}{*}{ Inventory } & - Stock of damaged material. \\
& - Stock in containers of current production. \\
& - Differentiated storage system. \\
\hline \multirow{3}{*}{ Movements } & - Not standardized workstation equipment. \\
& - Wrong spaced equipments. \\
& - Difficult access to the components. \\
\hline \multirow{5}{*}{ Defects } & - A lot of rejected parts. \\
& - Difficulties during assembly. \\
& - Long repair jobs. \\
& - Irregular operations. \\
\hline
\end{tabular}

Source: own.

Next step was to identify waste in regard to each operator and workplace. Tables 10 to 16 shows waste identify for each operator.

Table 10. Waste identify at first workstation

\begin{tabular}{|c|c|}
\hline Kind of waste & $\begin{array}{l}\text { Identified examples } \\
\end{array}$ \\
\hline Overproduction & - Accumulates $5-6$ levers for next post. \\
\hline Over processing & $\begin{array}{l}\text { - Mounted cap on lever and turn it over to grease Lever and } \\
\text { then put back well. } \\
\text { - After place Lever at Base, take out Base of the useful to } \\
\text { check the Semisocket Assembly. } \\
\text { - Reset on each lever because the station does not work well } \\
\text { (screwed Verifier). }\end{array}$ \\
\hline Movement & $\begin{array}{l}\text { - Container Bases are very deep. } \\
\text { - Levers are near frame side and must look out for catching it. }\end{array}$ \\
\hline Defects & $\begin{array}{l}\text { - Although the program gives information to the verification of } \\
\text { the bolted and placket, it does not lock the Lever and let fol- } \\
\text { low the following process but the Lever oiler not oiling. } \\
\text { - The alarms lights are activated when you press the bimanual } \\
\text { in case of eject Lever. }\end{array}$ \\
\hline
\end{tabular}

Source: own. 
Table 11. Waste identify at second workstation

\begin{tabular}{|c|l|}
\hline \multicolumn{1}{|c|}{ Kind of waste } & \multicolumn{1}{c|}{ Identified examples } \\
\hline \multirow{3}{*}{ Overproduction } & $\begin{array}{l}\text { - Accumulates 5 -6 levers for next post. } \\
\text { - They have no place to leave the levers made and they are left } \\
\text { on the bench in a disorderly way in the base of the next post. }\end{array}$ \\
\hline \multirow{3}{*}{ Over processing } & $\begin{array}{l}\text { - Take the spring from the shelf and mounts, and then take the } \\
\text { locking pin of the same shelf (2 movements of the arm). } \\
\text { - Fit parts in Kanban boxes }\end{array}$ \\
\hline \multirow{3}{*}{ Movement } & $\begin{array}{l}\text { - Moves from 2a to 2b to remove the lever, he goes back to the } \\
\text { 2a to grab the lever and made moves to 2b to put in useful } \\
\text { and press button, returns to 2a to mount and position lever in } \\
\text { useful. }\end{array}$ \\
& $-\begin{array}{l}\text { You must look out for catching them and parts back side } \\
\text { structure. }\end{array}$ \\
\hline
\end{tabular}

Source: own.

Table 12 . Waste identify at third workstation

\begin{tabular}{|c|l|}
\hline Kind of waste & \multicolumn{1}{c|}{ Identified examples } \\
\hline Overproduction & - Accumulates 5 -6 levers for next post. \\
\hline \multirow{4}{*}{ Over processing } & - 3a difficulty in positioning lever in useful to attach solenoid. \\
& - 3a difficulty in placing Solenoid in basis. \\
& - 3a wrap the Solenoid cables giving 2 laps. \\
& - Fit parts in Kanban boxes. \\
\hline \multirow{5}{*}{ Movement } & - 3a turns to leave lever in next station. \\
& - 3a the following do not have to leave the levers and lose time \\
& searching for it. \\
& - 3a moves from 3a to 3b to mount Solenoid in database and \\
& returns to 3a for screw Solenoid. \\
& - Very high benches (place a pallet on the floor to gain height). \\
\hline
\end{tabular}

Source: own.

Table 13. Waste identify at fourth workstation

\begin{tabular}{|c|c|}
\hline Kind of waste & Identified examples \\
\hline Overproduction & - Accumulates $5-6$ levers for next post. \\
\hline Over processing & - Fit parts in Kanban boxes. \\
\hline Movement & $\begin{array}{l}\text { - Detent away behind the lateral structure and must look out for } \\
\text { catching it. } \\
\text { - He turns to leave the lever in the tray of the next station. } \\
\text { - Superior joint very remote. } \\
\text { - Very high benches (place a pallet on the floor to gain height). }\end{array}$ \\
\hline Defects & - Checker Fails screwed. Reset on each lever. \\
\hline
\end{tabular}

Source: own. 
Impact of Kaizen solutions on...

Table 14. Waste identify at fifth workstation

\begin{tabular}{|c|c|}
\hline Kind of waste & Identified examples \\
\hline Overproduction & - Sometimes leave the levers on a shelf \\
\hline Over processing & $\begin{array}{l}\text { - Pink point mark in TF. } \\
\text { - Check TC CocoVikingo and plastic TF. } \\
\text { - Fit parts in Kanban boxes. }\end{array}$ \\
\hline Movement & $\begin{array}{l}\text { - Move to station 6, take out the lever and return to station 5, } \\
\text { grab the lever and returns to station 6, placed in useful and } \\
\text { drives bimanual. Returns to station 5. }\end{array}$ \\
\hline Defects & $\begin{array}{l}\text { - TC bad stapling. } \\
\text { - TF with broken "chimney". } \\
\text { - TF with broken tigger. }\end{array}$ \\
\hline
\end{tabular}

Source: own.

Table 15 . Waste identify at sixth workstation

\begin{tabular}{|c|l|}
\hline Kind of waste & \multicolumn{1}{c|}{ Identified examples } \\
\hline Overproduction & - Accumulates in tray for next post \\
\hline \multirow{3}{*}{ Over processing } & $\begin{array}{l}\text { - Joint glued bottom among them. The operator must come } \\
\text { off with considerable difficulty. } \\
\text { - Fit parts in Kanban boxes. }\end{array}$ \\
\hline Movement & - Lower joint loose on the bench. \\
\hline Defects & $\begin{array}{l}\text { - Lower joint bent and torn material. } \\
\text { - Cover badly wedged }\end{array}$ \\
\hline
\end{tabular}

Source: own.

Table 16. Waste identify at seventh workstation

\begin{tabular}{|c|l|}
\hline Kind of waste & \multicolumn{1}{c|}{ Identified examples } \\
\hline \multirow{3}{*}{ Overproduction } & - Take out lever of the useful and leaves in control table. \\
& - Returns up to tray and grab handle to put in useful. \\
& - Fill out the Final Check List sheet. \\
& - Makes labels NOK product. \\
& - Fit parts in Kanban boxes. \\
\hline Movement & - Very deep shipping container and has to lean. \\
& - Go to look for separators for shipping container. \\
\hline Defects & - Mistakes in the final check list. \\
\hline
\end{tabular}

Source: own.

The reasons of occur waste are identified through the use of quality tools, such as cause-and-effect diagram, control chart, Pareto chart, flow chart and also 5 why and failure mode and effects analysis. Removal of individual cases of waste was made possible by organizational changes, change psyche of employees, and also by small investment. After analyzing the causes of waste and ways of eliminating was formulate new labor standards for operators, which resulted in a shortening of cycle time. 


\section{MEASUREMENT FOR THE NEW LINE}

Actions taken in the context of improvement and involvement of employees contributed to a significant improvement on the analyzed production line. Figure 4 shows lay out of the line after kaizen activities.

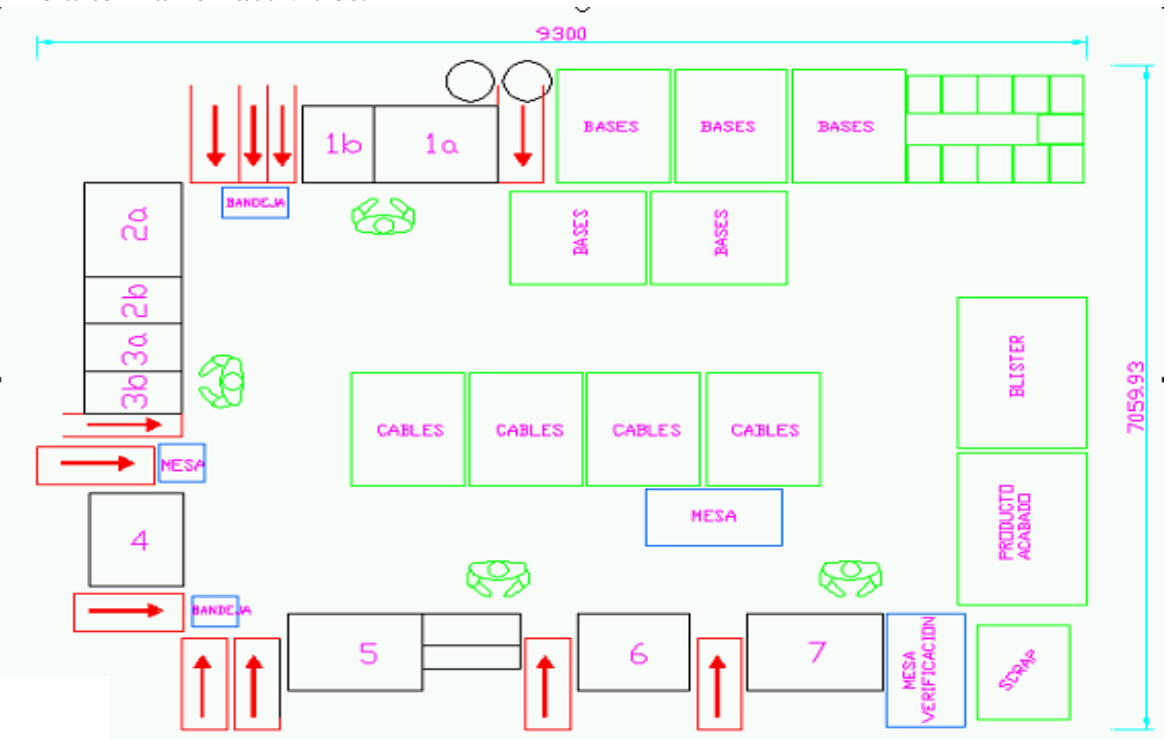

Fig.4. Layout of the line after kaizen activities

Source: own.

Table 17 shows new times that each operators need for each steps of his work after Kaizen.

Table 17.Time per operator - after Kaizen

\begin{tabular}{|c|c|c|c|c|c|c|c|}
\hline Operator no. & 1 & 2 & 3 & 4 & 5 & 6 & 7 \\
\hline Total time [sec] & 62,9 & 34,9 & 48,9 & 47,6 & 52,1 & 34,0 & 50,2 \\
\hline \multicolumn{8}{|c|}{ The cycle time is 330,6 seconds. }
\end{tabular}

Source: own.

Number of employees after changes has been the same, but volume of production increase to 482 pieces per day, it mean that new productivity is 4,3 pieces per operator per hour. Better use of production space reduce the need for production area from $55,8 \mathrm{~m}^{2}$ to $49 \mathrm{~m}^{2}$. Also work in progress are now under control and it takes 15 handles.

\section{CONCLUSIONS}

After an application of Kaizen solution for the analyzed production line there is still the same number of workers, but increasing the productivity. Each operator produces now 6 units more per turn. Cycle time was reduced by 30 seconds. With the new layout production line was using 15,8 square meters less than before. The summary of all results are shown in table 18. 
Table 18. Result of kaizen activity

\begin{tabular}{|c|c|c|c|}
\hline Concept & Before Kaizen & After Kaizen & Variation [\%] \\
\hline Production [units] & 392 & 482 & \multirow{2}{*}{23} \\
\cline { 1 - 2 } Production [seconds/unit] & 128,6 & 104,6 & \\
\hline $\begin{array}{c}\text { Productivity } \\
\text { [units/hour/person] }\end{array}$ & 3,5 & 4,3 & 14 \\
\hline Occupied surface [m ${ }^{2}$ ] & 55,8 & 49 & 50 \\
\hline Work in progress & 30 & 15 & \\
\hline
\end{tabular}

Source: own.

Pilot implementation of the concept of kaizen on one of the production line was a success, so management decided to implement kaizen on other lines. Kazien goals for the next line have been quantified, and the company developed its own way of communicating with employees, reporting kaizen ideas and rewarding employees who contribute to the continuous improvement of the company.

Implementation of the project confirms that creativity and employee involvement in improving their workplaces has a huge impact on productivity.

\section{ACKNOWLEDGMENT}

The presented results of the research, carried out under the theme No. 02/23/DS$\mathrm{PB} / 7677$, was funded with a grant to science granted by the Ministry of Science and Higher Education.

\section{REFERENCES}

[1] Asada T., Bailes J. C., Suzuki K., Implementing ABM with Hoshin Management, Institute of Management Accountants Publ., New Jersey 2000.

[2] Cheser R. N., The Effect of Japanese Kaizen on Employee Motivation in US Manufacturing, "International Journal Organizational Analysis" 2998, Vol. 6, No. 3.

[3] Imai M., Kaizen: The Key to Japan's Competitive Success, Random House Published, New York 1986.

[4] J. A. Marin-Garcia, J. J. Garcia-Sabater, T. Bonavia, The impact of Kaizen Events on improving the performance of automotive components' first-tier suppliers, "International Journal of Automotive Technology and Management" 2009, Volume 9, Issue 4.

[5] Karkoszka T., Honorowicz J., Kaizen philosophy a manner of continuous improvement of processes and products, "Journal of Achievements in Materials and Manufacturing Engineering" 2009, Volume 35, Issue 2.

[6] Liker J.K., Franz J. K., The Toyota Way to Continuous Improvement, Linking Strategy and Operational Excellence to Achieve Superior Performance, The McGraw-Hill Companies, United States of America 2011.

[7] Liker J. K., Meier D. P., Droga Toyoty Fieldbook. Praktyczny przewodnik wdrażania 4P Toyoty, Wyd. MT Biznes, Warszawa 2011.

[8] Musztyfaga M., Skoud B., Human resources management in a project type tasks, "Journal of Achievements in Materials and Manufacturing Engineering" 2007, 25/2.

[9] Norhasni M., Asaad M., Saad R., Yusoff R. Z., 5s, Kaizen and Organization Performance: Examining the Relationship and Level of Implementation Using Rasch Model in Malaysian Automotive Company, "International Academic Research Journal of Business and Technology".

[10] Ohno T., System Produkcyjny Toyoty. Więcej niż produkcja na duża skalę, ProdPress.com, Wrocław 2008. 
[11] Rother M., Shook J., Learning to see: value stream mapping to create value and eliminate muda, Brookline, Lean Enterprise Institute, Wrocław 1990.

[12] Suárez-Barraza M. F., Smith T., The Kaizen approach within process innovation: findings from a multiple case study in Ibero-American countries, "Total Quality Management \& Business Excellence" 2014, 25(9-10).

[13] Suzaki K, The New Manufacturing Challenge-Techniques of Manufacturing Systems, John Wiley and Sons, Inc., New York 1987.

[14] Titu M. A., Operan C., Grecu D., Applying the Kaizen Method and the 5 S Technique in the Activity of Post-Sale Services in the Knowledge-Based Organization, "Proceedings of the International MultiConference of Engineers and Computer Scientists" 2010, Vol. III, IMECS, Hong Kong.

\section{WPLYW ZASTOSOWANIA ROZWIAZZAŃ KAIZEN NA WYDAJNOŚĆ PRODUKCJI}

Celem artykułu jest wykazanie wpływu kreatywności i zaangażowania pracowników w doskonalenie własnych stanowisk roboczych na wydajność produkcji. Współczesne przedsiębiorstwa, chcąc sprostać dynamicznie zmieniającym się wymaganiom ze strony rynku, są zmuszone elastycznie reagować na potrzeby rynku pamiętając jednocześnie o zachowaniu odpowiedniego poziomu oferowanych produktów. W artykule przedstawiono przykład zaangażowania pracowników w działania doskonalące ich środowisko pracy. Model, w którym pracownicy są świadomi swojej pośredniej i bezpośredniej roli w procesie produkcyjnym i wpływie na jego realizację są podstawowymi założeniami Kaizen. Dzięki temu możliwe jest wykreowanie motywacji pracowników do udoskonalania swoich stanowisk pracy według własnych potrzeb i wymagań. Wybór tematu wynika z przekonania, że właściwa motywacja pracowników produkcyjnych przekłada się na wzrost ich zaangażowania w pracę, a doskonalenie własnego stanowiska produkcyjnego przekłada się na wzrost wydajności całego procesu. Właściwe wykorzystanie pomysłów pracowników, przynosi pozytywne efekty $\mathrm{w}$ postaci lepszego wykorzystania dostępnych zasobów przedsiębiorstwa. Artykuł zawiera przykład wykorzystania systemu sugestii pracowników w przedsiębiorstwie branży metalowej. Została dokonana analiza wydajności stanowiska roboczego przed i po wdrożeniu kaizen wraz z wdrożonymi rozwiązaniami doskonalącymi. Autorzy dzięki swoim badaniom wykazali, że im większe jest zaangażowanie ze strony pracowników w doskonalenie swojego miejsca pracy (które wynika bezpośrednio z systemu sugestii wdrożonego $\mathrm{w}$ danym przedsiębiorstwie), tym większa jest wydajność tego stanowiska.

Słowa kluczowe: Kaizen, Lean Manufacturing, doskonalenie, zaangażowanie pracownika, system sugestii pracownika

DOI: $10.7862 /$ rz.2016.mmr.53

Tekst złożono w redakcji: październik 2016

Przyjęto do druku: grudzień 2016 